\title{
Family Business Professors: Resources For Online Learning
}

\section{Kimberly Eddleston (Northeastern University)}

KEYWORDS: Information Technology, Teaching Methods.

Due to the Coronavirus (COVID-19) epidemic, many professors are quickly revising their courses to be delivered online. FamilyBusiness.org is here to help with an array of free and peer-reviewed resources that can easily be used in an online course. While the examples offered below are geared towards family business courses, our sister website - eix.org - offers a multitude of free and peer-reviewed resources geared toward entrepreneurship and innovation education.

We hope you find these resources helpful. Like family, FamilyBusiness.org is here to help and support you! Please follow us on Twitter at @EIXsocial (https://twitter.com/EIXSocial) if you would like to receive updates on our new content.

If you need help finding software and services to move your classes online, check out this article (https://familybusiness.org/content/technology-tools-forremote-teaching-and-student-mentoring) on EIX.

\section{Videos that showcase family business principles and give an insider's perspective:}

How Family Firms Can Innovate With Less

https://familybusiness.org/content/How-Family-Firms-

Can-Innovate-With-Less

'There's No Birthright' and Other Tips for Raising Entrepreneurial Leaders

https://familybusiness.org/content/Theres-no-birthrightand-other-tips-for-raising

\section{Advice for Non-Family Executives in Family Businesses}

https://familybusiness.org/content/advice-for-non-familyexecutives-in-family-busin

What it Takes to Build a Four-Generation Business https://familybusiness.org/content/What-it-takes-to-build- a-four-generation

Why Family Firms are Like Jenga

https://familybusiness.org/content/why-family-firms-arelike-jenga

Encouraging Family Business Members to go the Extramile

https://familybusiness.org/content/Encouraging-familybusiness-members-to-go-the-extra-mile

Hyannis Country Garden is a Family Business With Deep Roots

https://familybusiness.org/content/Hyannis-countrygarden-is-a-family-business-with-deep-roots

\section{Exercises and activities that can be performed remotely:}

Understand Your Family Firm's Core Strengths and Weaknesses

https://familybusiness.org/content/understand-yourfamily-firms-core-strengths-and-weaknesses

Unlocking the Innovation Potential of Family Firms: An Assessment Tool

https://familybusiness.org/content/unlocking-theinnovation-potential-of-family-firms-an-assessment

Let's Get Professional: Family Firms Need HRM Practices

https://familybusiness.org/content/Lets-get-professionalfamily-firms-need-hrm

Future Family Business Owners Can Learn to Manage Conflict
Copyright @ 2020 The Authors. Entrepreneur \& Innovation Exchange is published at EIX.org. This is an open access article under the terms of the Creative Commons Attribution-NoDerivs License, which permits use and distribution in any medium, provided the original work is properly cited and no modifications or adaptations are made. View EIX.org Authorship Terms at https://eix.org/terms
FamilyBusiness 
https://familybusiness.org/content/future-familybusiness-owners-can-learn-to-manag

Acres of Diamonds: Advantages of Working in Your Family Business

https://familybusiness.org/content/acres-of-diamondsadvantages-of-working-in-your

\section{Cases that can easily spur online discussion and debate:}

How Lowell Wakefield Made Crab King

https://eiexchange.com/content/231-how-lowellwakefield-made-crab-king

(https://familybusiness.org/content/231-how-lowell-

wakefield-made-crab-king)

How Can the Family Business Cope When a Key Nonfamily Exec Leaves?

https://familybusiness.org/content/how-can-the-familybusiness-cope-when-a-key-non

\section{Readings materials well-suited for family business education:}

\section{Outside Leadership Can Save the Family Business}

https://familybusiness.org/content/Outside-leadershipcan-save-the-family-business

Thriving or Trapped in the Family Business

https://familybusiness.org/content/thriving-or-trapped-inthe-family-business

Too Much Love in the Family Can Hurt

https://familybusiness.org/content/Too-much-love-in-thefamily-can-hurt

How Family Business Leaders Can Encourage Both Devotion and Performance

https://familybusiness.org/content/How-family-businessleaders-can-encourage-both-d

The Family Way: How Entrepreneurial Values Help Businesses Thrive Over Generations

https://familybusiness.org/content/the-family-way-how- entrepreneurial-values-help-b

The 'Fredo Factor:' How Deadbeats and Troublemakers Hurt Family Businesses

https://familybusiness.org/content/the-fredo-factor-howdeadbeats-and-troublemakers

\section{Successful Successions Are Never Smooth}

https://familybusiness.org/content/successfulsuccessions-are-never-smooth

When Entrepreneurs Raise Entrepreneurs

https://familybusiness.org/content/When-entrepreneursraise-entrepreneurs

Finally, for a list of additional cases, TV shows and movies that could be incorporated into your online course, the following article is excellent:

Case Studies, Movies, TV Shows and Other Family Business Resources

https://familybusiness.org/content/case-studies-moviestv-shows-and-other-family-bu

From our family to yours, FamilyBusiness.org wishes you the best!

Additional Search Terms: online teaching, online classrooms, teaching remotely, remote learning 